\title{
KIT NP_000213.1:p.W557R
}

National Cancer Institute

\section{Source}

National Cancer Institute. KIT NP 000213.1:p.W557R. NCI Thesaurus. Code C158901.

A change in the amino acid residue at position 557 in the mast/stem cell growth factor receptor Kit protein where tryptophan has been replaced by arginine. 